\title{
Prioritising career guidance and development services in post-apartheid South Africa
}

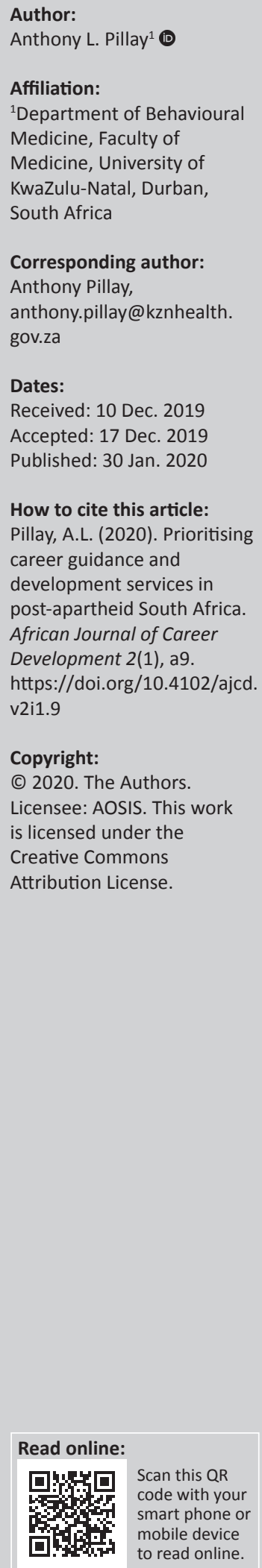

Career guidance and development services must be viewed as a priority, especially given Africa's history of colonisation and deprivation where people of colour were viewed essentially as manual labour. With decolonisation efforts and improved opportunities, the impact of poorly informed career decisions is a concern. This can be quite serious both individually and nationally, and attempts must be made to address this problem. Young people and their families affected by ill-conceived or absent career planning suffer economically and psychologically. Considering the global and local economic trends, job markets and youth unemployment, career guidance services must take cognisance of the transformed workspace to include the informal employment sector. Most importantly, career guidance services must be made available to all, and not just a select few.

Keywords: career; guidance; counselling; student; work; employment.

\section{Introduction}

The idea of career development is in many ways a conception of the modern era, considering that careers were chosen, modified, adapted and even completely changed, based on a variety of factors that did not include the intervention of a career development practitioner. The history of work suggests that in earlier times, individuals went into jobs rather than careers. In this context, it has been argued that a job is something one does simply to earn money, while a career is a sequence of related opportunities and activities that provide the experiences necessary to develop one's future, and involves going beyond the minimum contractual work obligations (Roth, 2008). Of course, the two concepts are not mutually exclusive and have bearing and relevance in various employment contexts, more so those where work opportunities are scarce.

The extent to which poorer countries are able to offer its citizens the opportunities for careers may appear to be limited - or is that necessarily so? The priority in middle- and low-income countries is obviously to provide jobs for all to ensure adequate standards of living, nutrition, housing, schooling and health care, among other necessities. Unfortunately, in many nations, those minimum standards are not met because of broader economic and socio-political factors that militate against the development of sufficient formal employment opportunities. South Africa has been one of the countries where formal sector employment opportunities have been shrinking quite significantly over many years, resulting in a rather bleak economic and development outlook, especially for young adults.

The current economic situation in South Africa is rather worrying, with many financial and other indices causing considerable uneasiness. The unemployment rate of almost $30 \%$ means much poverty and despair, and this is etiologically related to many social, health and legal problems. Worst unemployment rates are among the young with $58.2 \%$ of $15-24$-year olds and $36.1 \%$ of 25-34-year olds unemployed (Statistics South Africa, 2019). This means that many first-time work seekers are not able to secure a job, let alone develop a career. Nevertheless, it is important that both targets (i.e. job provision and career development) are kept high up on the economic and development agenda.

With the reduction in formal sector employment opportunities, a certain vibrancy in the informal sector has been evident across the African continent, as well as in Asia and South America. Commenting on the South African situation, Altman (2003) noted several years ago that the main growth trends in employment have been outside the formal sector. Of course, many of these initiatives have been individual-based and born out of desperation. Notably also in the process of desperately trying to carve out an income generation opportunity, many have demonstrated remarkable ingenuity and creativity, resulting in them surpassing what might have been, had 
they gained employment in the formal sector. For such individuals and employment contexts, career development is also relevant, perhaps even more so in some ways, considering that these individuals are working on their own without being part of a larger organisational structure that allows for or is geared towards career development trajectories.

It is clear that much has changed in the world of work, job supply, job training and preparation, educational curricula as well as the science of careers and career development. With the advent of the career development practitioner as a relatively recent professional specialty, it is important to recognise that this area of focus has a much earlier history, dating to the late 19th century. Frank Parsons, who is credited with being a founding figure in the field of career counselling, paved the way for much of what was to follow in the area, including innovations such as vocational guidance in schools and the training of vocational counsellors (Jones, 1994). He saw this as a service to 'aid young people in choosing an occupation, preparing themselves for it, finding an opening in it, and building up a career of efficiency and success' (Parsons, 1908, p. 3). In many ways, this reflects some of the contemporary aims of career counselling over a century later.

Across the world, it is evident that a range of professionals has been involved in providing career development services. These have included psychology professionals, human resource practitioners, education specialists and others. Moreover, the professional designations of those involved in providing career counselling and development services have varied over time and place, perhaps creating some confusion for consumers. An Australian survey of career development practitioners identified over 90 different titles used to denote the professionals performing this area of work (Athanasou, 2012). While the same extent of variation may not be present on the African continent, given the general shortage of specialist skills in the area, it is likely that, where such services are available, there are different service provider designations involved. This is certainly an issue that needs addressing however, the greater need on the continent lies in the provision of career development services.

\section{Historical issues in South Africa}

Career guidance and counselling services are not new in South Africa. In fact, such services have been available for several decades in the country and are well known in certain sectors of the population. Unfortunately, the services were available only to a select few, coinciding with the racist apartheid policies that favoured specifically the country's white minority. Like with all other services and privileges, the government of the day ensured that the country's black majority was denied such opportunities.

Of course, even long before the creation of apartheid, the colonisers of the African continent and other lands treated locals and those whom they shipped in from other parts of the colonised world as slave labour. These individuals had little or no choice in the work sphere that they entered. The pattern continued even after bondage and indenture ceased, and people in these communities were destined for menial jobs regardless of their abilities and potential. The apartheid system of education, work opportunities and job reservation simply followed that trend, perhaps mildly sanitised in some ways.

The social structure and education system of apartheid allowed for children of white parents and those in elite or more expensive schools to have access to some level of career guidance services. Commenting on the situation at the time, Watts (2009) noted:

[T] he gulf between the opportunities available to white people and to black people, and the way in which this was reflected in the structure and nature of career guidance services. (p. 7)

Apart from not affording children of colour appropriate career guidance services within the wider unequal education system, this served another apartheid goal, namely to ensure that black people were more restricted to menial jobs rather than advancing into professional roles. The government of the day had no interest in furthering the aspirations, goals or career development of black South Africans - in fact, to do so would have undermined its policy of oppression of the country's majority and the suppression of their progress and development.

Essentially, children of colour had no access within the school system to direction and guidance regarding choice of careers and secondary school preparation. For example, when it was time to select subjects in the secondary school years, most black children had little or no guidance on the choices to make in relation to career preferences or how these would benefit or hinder their career goals. This was compounded by the fact that the vast majority of black parents were not equipped to adequately advise their children on career planning. Having been academically restrained by apartheid policies, most were in nonprofessional careers. In this context, psychologists aided and abetted crimes against humanity by suggesting that black people were not suited to academic education (Fick, 1939). Parents, therefore, did not have the benefit of higher education and, as a result, had limited knowledge and experience of the tertiary education and vocational training sectors. This meant that many of the country's young people went into careers and even tertiary education programmes without appropriate advice, resulting in considerable fallout - this is still the situation for many.

While access to career counselling services was historically based on variables of privilege, it is crucial that this service should not be viewed as a privilege, especially as it pertains to secondary and tertiary education students. For this group, the consequences of not having proper career guidance can be dire. Having to make such significant life-altering decisions can be rather daunting and even paralysing for some. In this context, Robertson (2013) argues that career guidance aims to empower individuals to take a proactive approach, and it seeks to arm them with the belief that they have the ability to direct the course of their lives. In other 
words, career counselling services can promote a feeling of agency in the young person, especially considering that it may be one of the first major life decisions they have to make. Such feeling of agency and control over important life decisions can instil much confidence in young people, which ultimately enhances their ability to cope with further education and training.

\section{Consequences of inadequate career planning}

In South Africa, and elsewhere in the world, it is evident that a great many students embark on higher education and training without a clear idea of their career goals or life plan. For several young people, this is related to the circumstances of impoverishment in which a large portion of our population live. Many students, in their desperate attempt to find a way out of poverty, believe that further education is the key, but have little or no idea of the precise path to follow, what they are best suited to as a career or what the job opportunities and market forces are in the field that they are contemplating. These are serious issues, especially considering the developmental stage at which students complete their secondary schooling and have to ponder these career decisions. They could be as young as 16 or 17 years (or even earlier when they select their secondary school subjects), when brain development is hardly complete or sufficiently mature to make major decisions (Dumontheil, 2016). At this developmental stage, adolescents have to make rather critical life design decisions that will have long-term consequences affecting their work life and mental well-being. In this context, Maree, Pienaar and Fletcher (2018) argued that interventions in the area of life design are integrally related to identity development, and these are both critical to the young person's future growth and place in society, enabling successful outcomes.

Moreover, it is important to recognise that the fallout of poor career decision-making or the absence of career and vocational guidance and counselling services does not only affect the individual. The economic impact for families and the nation are considerable. Young people embarking on higher education and training without careful consideration of the longer-term career prospects, the job market and their employability thereafter, or the suitability of the career to their personality make-up can find themselves in a difficult situation later. Consequences, including unhappiness in the career or poor performance, are just some of the likely scenarios. An inability to complete the training is another common result. These negative outcomes can come at huge costs both financially and emotionally for the individual and family. In poor communities, such situations can have devastating impact as families count on positive returns from the investment being made in young people's education.

At a national level, poor career decisions have significant economic effect, especially where this impacts on the students' inability to complete their studies. Students failing to graduate during the required time or dropping out of higher education incur greater expense, considering that many programmes are government funded or subsidised to some extent. In countries where opportunities for higher education and training are limited, every student dropping out of a course corresponds to a lost opportunity for another. In addition, it reflects a loss of funding that could have been used elsewhere including vital services such as health care. In the case of students on government funding and financing schemes, such a situation could mean significant national debt that can be ill-afforded in poorer economies.

A further, more serious consequence of poor career decisions is the mental health sequelae for young students. Apart from the financial and other setbacks and difficulties, there are psychological sequelae. It is true that students who are unable to cope with higher education suffer significant emotional reactions to failure in their academic work. Investigating depressive symptoms in a sample of students attending a historically disadvantaged tertiary institution, a recent South African study revealed that almost one-quarter reported feeling overwhelmed by their studies and $7 \%$ had thoughts of killing themselves (Pillay, Thwala, \& Pillay, 2019). Depressive illness is currently regarded as a serious threat in tertiary education students and has been found to be higher than in the general population (Ibrahim, Kelly, Adams, \& Glazebrook, 2013). Suicidal behaviour among students has increased concern about the well-being of this group and has intensified calls for mental health support and intervention (Njilo, 2018). While not all depression or suicidal behaviour in higher education students is necessarily because of difficulty with academic work or poor selection of courses of study, this area of stress features strongly among student concerns (Pillay et al., 2019).

The literature and research into career guidance and planning have noted their importance in assisting individuals, and especially young people, in developing their life plan and facilitating healthy adjustment. Robertson (2013) has urged the career guidance community to engage in more research into its value in promoting well-being, arguing that even though the evidence base is in its early stage, there is much reason to support the profession's role in health and wellbeing promotion. In the context of life design counselling, Maree (2015) pointed to its significance in promoting adjustment, especially in its ability to help people better understand themselves and enhance their career decisionmaking abilities.

\section{Future concerns and recommendations}

Adolescents make decisions about careers in various ways and based on many factors that may not be as relevant to the final outcome. Among these is the growing use of the internet and related material to influence their decisions. Recent research showed significant correlation between internet use and effective career decision-making (Sinkkonen, Puhakka, \& Meriläinen, 2018). With young people increasingly reliant on online platforms for information and contemplating their 
future, it is important that formalised, reliable and effective career guidance services are available to help them make the best possible choices. While online career guidance resources appear to have proliferated remarkably in the digital era, cautions have been raised against the reliance on a purely online career guidance approach. The need for individualised, in-person support in the context of assessment procedures has been noted, considering that this facet can be a significantly absent variable in some of the assessment and guidance formats. It has been advocated that online assessments are best supplemented with support from a career guidance professional (Nelson, 2013).

Importantly, career development services should be made available to all who need it, unlike in the past. It is also critical that these opportunities are available to those involved in activities outside the formal sector.

Considering the creativity and innovative thinking that is needed in a fairly saturated formal job market, younger people seeking to carve out a niche for themselves are in need of much support and encouragement. Therefore, career guidance models and theoretical frameworks may need adjustment and repositioning to ensure that all are catered for, especially in low- and middle-income countries. Counsellors are compelled to innovate and contextualise their career counselling service in a way that will enable people to retain, promote and, in some instances, regain their employability in the gig economy (Maree, in press). Like the criticisms levelled at psychology and psychotherapy models amidst the need for transformed approaches relevant to all who need care, it is vital that career guidance, development and counselling practice are cognisant of the transformation agenda and are geared towards providing appropriate services. In time, the profession may well be judged, like psychology, on its ability to provide contextually relevant services. It has been suggested that any intervention that can serve to help people overcome social exclusion and marginalisation can have a positive impact on health and well-being (Robertson, 2013).

It has become evident that with global developments, economic challenges and competitive job markets, job insecurity is likely to be a common thread through the lives of workers. Equally, the possibility of job stability and permanence may decline. For these reasons, it has been argued that adaptability is going to be a critical 'survival skill' that people need to develop within the work environment (Maree, 2015). The more young people are taught about and coached in developing this ability, the better able they will be to sustain themselves in future unstable job markets. This may be one of the 'future-proofing' capacities that can enable workers to cope with the economic challenges they could face in the years ahead.

\section{Conclusion}

Against the background of severe deficiencies in career guidance and counselling services for South Africa's majority, it has to be said that many of those deficiencies are still prevalent in numerous schools. Furthermore, the general state of many schools, especially those in non-urban communities, is very poor despite the country's transition to democracy a little over 25 years ago. Considering also the shrinking job market, education costs and other challenges facing the youth, the need for career guidance for the country's young people is as great as ever.

Children at secondary school level are in dire need of career counselling and guidance services to enable them to make the best possible choices, thereby reducing the short- and long-term fallout that occurs with ill-considered decisions. It is critical to remember the vast inequality in South African society which sees some children growing up in homes with highly educated, professional parents who are able to offer advice on career options, not to mention educate their children in expensive private schools that provide various levels of career advice. On the other hand, the majority of the country's children have none of these opportunities, with many attending dilapidated schools that lack even the barest essentials, and some grow up in child-headed households without any parents or adults to guide them. These children face challenges that some of us cannot imagine, but which society, government and the education system must work towards eradicating - they need and deserve a brighter future and a better life. Helping Africa's children gain a foothold into a decent work opportunity must be a priority, and it is the least that the continent must strive to give them.

\section{Acknowledgements Competing interests}

The author has declared that no competing interests exist.

\section{Author's contributions}

I declare that I am the sole author of this research article.

\section{Funding information}

This research received no specific grant from any funding agency in the public, commercial, or not-for-profit sectors.

\section{Data availability statement}

Data sharing is not applicable to this article.

\section{Disclaimer}

The views and opinions expressed in this article are those of the author and do not reflect the official policy or position of any affiliated agency of the author.

\section{References}

Altman, M. (2003). The state of employment and unemployment in South Africa. In J. Daniel, A. Habib, \& R. Southall (Eds.), State of the nation: South Africa 2003-2004 (pp. 158-183). Cape Town: HSRC Press.

Athanasou, J.A. (2012). Career development practitioner survey analysis. Hawthorne, CA: Career Industry Council of Australia.

Dumontheil, I. (2016). Adolescent brain development. Current Opinion in Behavioral Sciences, 10, 39-44. https://doi.org/10.1080/03069885.2018.1455169

Fick, M.L. (1939). The educability of the South African native. Pretoria: South African Council for Educational and Social Research. 
Ibrahim, A.K., Kelly, S.J., Adams, C.E., \& Glazebrook, C. (2013). A systematic review of studies of depression prevalence in university students. Journal of Psychiatric studies of depression prevalence in university students. Journal of Psychiatr
Research, 47(3), 391-400. https://doi.org/10.1016/j.jpsychires.2012.11.015.

Jones, L.K. (1994). Frank Parsons' contribution to career counseling. Journal of Career Development, 20(4), 287-294. https://doi.org/10.1007/BF02106301

Maree, J.G. (2015). Research on life design in (South) Africa: A qualitative analysis. South African Journal of Psychology, 45(3), 332-348. https://doi. org/10.1177/0081246314566785

Maree, J.G. (in press). Innovating counseling for self- and career construction Connecting conscious knowledge with subconscious insight. New York: Springer.

Maree, J.G., Pienaar, M., \& Fletcher, L. (2018). Enhancing the sense of self of peer supporters using life design-related counselling. South African Journal of Psychology, 48(4), 420-433. https://doi.org/10.1177/0081246317742246

Nelson, R. (2013). Self-guidance using online databases. In G. Iannis \& V. Pinzi (Eds.) New technologies for career guidance and mobility: Handbook for practitioners (pp. 40-46). Siena: Industrßia Grafica Pistolesi.

Njilo, N. (2018). Wits to increase counselling services capacity after third student suicide this year. Timeslive. Retrieved from https://www timeslive.co.za/news/ south-africa/2018-10-25-wits-to-increase-counselling-services-capacity-afterthird-student-suicide-this-year/
Parsons, F. (1908). The vocational bureau. The Arena, 40, 3-16.

Pillay, A.L., Thwala, J.D., \& Pillay, I. (2019). Depressive symptoms in first year students at a rural South African university. Journal of Affective Disorders. Retrieved from https://doi.org/10.1016/j.jad.2019.11.094

Robertson, P.J. (2013). The well-being outcomes of career guidance. British Journal of Guidance \& Counselling, 41(3), 254-266. https://doi.org/10.1080/03069885.201 3.773959

Roth, J.D. (2008). The difference between a career and a job. Retrieved from https:// www.getrichslowly.org/the-difference-between-a-career-and-a-job/

Sinkkonen, H., Puhakka, H., \& Meriläinen, M. (2018). Adolescents' internet use in relation to self-esteem and adaptability in career decision-making. British Journa of Guidance \& Counselling, 46(6), 738-751. https://doi.org/10.1080/03069885.2 018.1455169

Statistics South Africa. (2019). Quarterly labour force survey: Quarter 3: 2019 statistical release P0211. Pretoria: Statistics South Africa. Retrieved from http:// www.statssa.gov.za/publications/P0211/P02113rdQuarter2019.pdf

Watts, T. (2009). The role of career guidance in the development of the National Qualifications Framework in South Africa. In South African Qualifications Authority (Ed) Career guidance challenges and opportunities (pp. 7-13). Pretoria: South African Qualifications Authority. 